\title{
Guest Editor's Introduction: French Sociology, French Sociologies
}

\author{
Julien Larregue ${ }^{1}$
}

Published online: 7 July 2017

(C) Springer Science+Business Media, LLC 2017

From Montesquieu to Piketty, French intellectuals have been a major source of inspiration for American academics. This is particularly true of sociology and social theory, where scholars such as Durkheim, Bourdieu or Latour have had a decisive influence on past and present research (Ollion and Abbott 2016). Yet, partly because of the language barrier, French sociology somewhat takes time to travel to the other side of the Atlantic. But it is not just a matter of translation or, for what it's worth, French people's terrific English accent (and vice versa). As Etienne Ollion and Andrew Abbott underlined, lack of familiarity with each other's field, diverging scientific norms of research and writing style, as well as differences in trending methods and topics can also explain difficulties to incorporate French sociology into its US counterpart (2016, pp. 345-348). In order to answer this time lag, The American Sociologist has decided to publish a special issue about the present situation and future prospects of sociology in France and French-speaking countries/territories. ${ }^{1} \mathrm{We}$ are very pleased to present to the American readership twelve papers shedding light on French sociology or, as I should rather say, French sociologies. While the papers that we were able to gather are rich and varied, they can roughly be grouped in three - overlapping - categories. I will begin by giving a brief outline of the papers, before mentioning some future research avenues and current controversies surrounding French sociology's scientific authority.

The first category, that comprises seven papers, deals with particular subfields or research questions: sociology of deviance and criminology (Mucchielli 2017), sociology of international relations (Meszaros 2017), sociology of aging (Burnay et al. 2017),

\footnotetext{
${ }^{1}$ Lawrence Nichols and I have tried to primarily focus on the current state of French sociology, rather than on its history and past forms. For those readers who are more interested in historical analyses, we can only refer to the plethora of thorough investigations that addressed the works of Durkheim and his legacy (see for instance Heilbron 2015). Some of the featured papers do include historical perspectives (in particular Meszaros 2017; Mucchielli 2017)
}

Julien Larregue

Julien.larregue@univ-amu.fr

1 Law School, LDPSC EA 4690, Aix-Marseille Université, Aix-en-Provence, France 
cognitive sociology (Sepulvado and Lizardo 2017), social network analysis (PenalvaIcher and Eloire 2017), sociology of gender (Kabile and Lefaucheur 2017), sociology of ethnicity (Brahim 2017).

Laurent Mucchielli provides a socio-historical perspective on the sociology of deviance in France (2017). Starting in the late nineteenth century, the author provides a broad overview of the successive states of the field. From classical French sociologists, including Gabriel Tarde and Emile Durkheim, who sought to distance themselves from biological frames of reference, followed by the contribution of physicians and legal scholars in the first half of the twentieth century that would culminate in the aftermath of the Second World War with a first failed attempt to institutionalize criminology, to the 1970s when the constructivist sociology of deviance that developed in the US and United Kingdom would come to dominate the French field, until a more recent attempt (between 2007 and 2012) to implement criminology departments in French universities would again fail to convince academics and administrators.

In the same vein, Thomas Meszaros proposes an overview of the French sociological tradition of international relations from the eighteenth century to today (2017). Focusing on post-war prominent figures Raymond Aron and Marcel Merle, Meszaros show how and why the French School of international relations has been divided in two distinct intellectual lineages, with Aron being mainly influenced by German theorists such as Max Weber and Carl von Clausewitz, while Merle's works are primarily anchored in Durkheim's and Mauss'. This article also sheds light on the relations between the sociological tradition of international relations and those developed in other related disciplines, including history and law.

Nathalie Burnay, Cornelia Hummel and Ingrid Voléry offer an analysis of the sociology of aging in three French-speaking countries: France, Switzerland and Belgium (2017). Through a systematic literature review of articles published in generalist and specialized sociology journals (including Revue française de sociologie, Revue suisse de sociologie and Recherches sociologiques et anthropologiques), Burnay, Hummel and Voléry show how national disciplinary dynamics impact the treatment of aging in sociological literature, including its lack of visibility in the most prestigious journals, as well as the pronounced interdisciplinary exchanges and implementation of a new relatively autonomous research field.

Brandon Sepulvado and Omar Lizardo delve into French cognitive sociology (2017). Although one could think that the subfield is homogeneous, the authors distinguish between three main branches: one centered around the question of beliefs and rationality (promoted by famous French sociologist Raymond Boudon), the second aimed at grounding sociology on a naturalistic framework, and the third inspired by linguistics. The distinction is not purely theoretical; in pragmatic terms, Sepulvado and Lizardo explain how the different branches of French cognitive sociology are more or less reconcilable with their American counterparts.

Adopting a sociology of science perspective, Elise Penalva-Icher and Fabien Eloire investigate Social Network Analysis in France (2017). Penalva-Icher and Eloire focus on five main disciplinary entrepreneurs, showing how the progressive development and institutionalization of Social Network Analysis required the use of three different "languages": English, Mathematics, and Computer Science. This case study furnishes an interesting example of inter-field exchanges and translation. Indeed, while French social scientists borrowed some of their methodological and conceptual tools from their 
US colleagues, they managed to adapt them to the specific intellectual heritage they belonged to.

Nadine Lefaucheur and Joelle Kabile provide an overview of the sociology of gender in the French Caribbean (2017). The situation of sociology in the West Indies is highly peculiar, and thus fascinating; as Lefaucheur and Kabile explain, due to - very - limited resources and to historical and institutional resistance, the local university does not offer any degree in sociology. Research is thus decoupled from academic training, the absence of graduate students rendering it more difficult to develop lasting research programs. At the same time, Martinique's and Guadeloupe's geographic location foster scientific collaborations with, and conceptual borrowings from, English-speaking and Spanish-speaking gender specialists.

Rachida Brahim's article constitutes a first-hand example of French sociology of ethnicity (2017). Underlining the essential influence of English-speaking research and the lack of institutionalization of the sociology of ethnicity in France, Brahim proposes an analysis of racially motivated violence in 1970s' Marseille through Foucault's concept of biopower. Although American researchers have frequently used and discussed the works of the French social theorist, Brahim regrets that French sociologists have seldom applied his concepts to the study of ethnicity. Confronting this relative - color blindness, Brahim's article opens up a promising research avenue for anyone interested in the dialog between governmental racism and ethnicity.

Another category of contributions, comprising three papers, focuses on the scientific reception of, and controversies surrounding, prominent French social scientists: Pierre Bourdieu (Faber 2017), Thomas Piketty (Raoult et al. 2017), and Emmanuel Todd (Verjus 2017; see also my brief biographical notice on Todd: Larregue 2017).

Agoston Faber seeks to refute one recurrent criticism directed at Bourdieu's sociology, that of a so-called sociological determinism (2017). While acknowledging that Bourdieu has theoretically neglected the question of agency and individual deliberative action (a task that his former student Luc Boltanski has been dealing with), Faber shows that accusing the French social theorist of determinism is excessive and misleading. Even though Bourdieu does not say much about the concrete ways in which one could escape his social destiny, his analyses of the mechanisms of domination and reproduction were precisely aimed at developing and providing emancipating tools. Bourdieu's social theory should thus rather be seen as a "sociology of emancipation" than as an example of sociological determinism (Faber 2017, p. 15).

Thomas Piketty's Capital in the Twenty-First Century is yet another example of controversy involving a prominent French social scientist (Raoult et al. 2017). In their article, Sacha Raoult, Brendan Leonard and Arnaud Derbey adopt a sociology of science perspective to provide a comparative analysis of the reception of Piketty's bestseller in France and the United States. Despite the numerous cultural and structural differences existing between the French and US social science fields, the authors show that the book reviewers are first and foremost guided by their disciplinary training. The more or less positive or negative review's content is thus determined by internal academic concerns rather than by external public ones.

Anne Verjus defends Emmanuel Todd's controversial Who is Charlie? (2017; for a biographical presentation of Todd, see Larregue 2017). Todd's book has been published in the aftermath of the 2015 Charlie Hebdo's terrorist attacks in Paris. Its main argument, that the public demonstrations that followed these events were motivated 
by an islamophobic secularism, has steered both public and academic controversies. Responding to its critics, Verjus supports the methodology of Who is Charlie? and laments researchers' reactions to the book. In particular, she argues that Todd's reject is to be explained by a lack of reflexivity among social scientists. Since the educated middle-class (including academics and journalists) has been very active during the waves of demonstration, rather than confronting the truth, academics tried to dismiss it.

The last category of papers adopts a reflexive posture to shed light on the production of sociological science in France. One is about the practice of the corporate sociologist (Jeannin 2017), while the other focuses on the place of the individual in French sociology (Masson and Schrecker 2017).

Hélène Jeannin proposes an insider's view of what it is to be a corporate sociologist (Jeannin 2017). A researcher at Orange, one of the main telecommunication groups in France, Jeannin analyzes the financial, strategic, and organizational constraints attached to the position of corporate sociologist. Discarding the simplistic view that sees in the corporate scientist an industrial servant, Jeannin distinguishes between the company's official communication and its researchers' posture. While acknowledging the somewhat precarious position of corporate sociologists, including the potential strains between scientific and industrial interests, this article shows how sociology can benefit from corporate resources, especially in an era where the French government regularly cuts funding to (social) science.

Philippe Masson and Cherry Schrecker focus on the conceptual and methodological practices of French sociologists as regard to the individual (2017). Long dominated by the Durkheimian holist macrosocial tradition, French sociology has, since the 1980s, progressively incorporated individual-level questions (emotions, bodies, sensations, etc.). This evolution owes much to the American influence, in particular to Chicago's ethnographic school. Yet, as underlined by Masson and Schrecker, the growing place of the individual in sociological study design does not necessarily mean that it gained visibility at the theoretical level, the collection of individuals being sometimes a proxy variable to study structural and cultural phenomena.

Read together, these twelve papers provide a fine-grained analysis of French sociology and of its differences and similitudes with its US counterpart. I began my editorial introduction by underlining the French influence on North American sociology. What we learn from several of these contributions is that the influence works in both directions. French social scientists have too been influenced by their American colleagues, for instance in their study of deviance and crime (Mucchielli 2017), but also in their conceptualization of the individual (Masson and Schrecker 2017). To be sure, French and US sociologies do present major differences. Some areas of research, such as the sociology of ethnicity (Brahim 2017) and gender (Lefaucheur and Kabile 2017) or Social Network Analysis (Penalva-Icher and Eloire 2017), are under-developed in France in comparison with the US. Conversely, French sociologists have sometimes been precursors and inspired their US colleagues, as in the case of cognitive sociology (Sepulvado and Lizardo 2017). But differences between US and French sociologies should not be readily assumed. The reception of Piketty's Capital in the Twenty-First Century constitutes a noticeable example where supra-national disciplinary interests are more adequate to understand scientific processes than nationalist frames of reference (Raoult et al. 2017). This, I think, is one of the main contributions of this special issue: we see no clear pattern emerging. 
We should continue our efforts to understand the structuration and functioning of the sociological field in France. In this regard, one promising research avenue concerns professional associations and, more generally, the discipline's ability to foster its social authority, both within and outside of the scientific field. For instance, one could investigate the history and development of the Association française de sociologie (French Sociological Association) and compare it with the American Sociological Association. In the same vein, analyzing generalist and specialized journals of sociology would be an interesting angle to answer a series of questions regarding the discipline's autonomy vis-à-vis related social science fields (such as political science, economics or law). Regarding the career itself, one can choose between a wide array of paths to become a sociologist in France. To name just a few, one can either enter the CNRS (French National Center for Scientific Research), the university system (as a professor), a public research-oriented institution such as the Ecole des hautes études en sciences sociales or the Ecole normale supérieure, and of course an industrial company such as Orange (Jeannin 2017).

I would like to end up this editorial by saying a few words about sociologists' difficulties to impose their social authority in France. As in the United States, French social scientists have had a hard time convincing fellow scientists, politicians, and lay people alike that their productions were sound, trustworthy and useful. In a nutshell, that they were, too, rigorous scientists. But French sociologists have addressed the problem of scientificity and utility differently than American sociologists did. While US sociology has somewhat tried to imitate natural sciences and its deductive model of interpretation, which is visible in the structure of articles with the now classic IMRAD presentation (introduction-methodology-results-discussion), French sociologists have continued to communicate their results in an "idiographic style" (Ollion and Abbott 2016, p. 347). Rather than adopting the dominant scientific model, most French sociologists have sought to cultivate their specificities. For instance, in his book Le raisonnement sociologique: un espace non-poppérien de l'argumentation, prominent sociologist Jean-Claude Passeron argued that sociological research was not concerned by Popper's imperative of falsifiability due to its particular modes of reasoning and deduction (2013). Rather, sociological discourses should be subject to what Passeron called objectabilité. ${ }^{2}$ Sociology is scientific when objectable: if there is nothing to object to, then nothing is proven.

More recently, Bernard Lahire addressed yet another recurrent popular criticism aimed at sociology, that of the culture de l'excuse (2016). Sociologists have indeed long been accused of providing deviant people with excuses. By translating individual behaviors into social phenomena, sociology would prevent individuals from being held responsible for their actions and personal choices. Although this accusation is dated, it recently stirred controversy again when then Prime Minister Manuel Valls publicly declared to the French Senate in November 2015, following the terrorist attacks that had taken place in Paris, that "explaining Jihadism, it's already being willing to excuse it a bit" (Valls also used the phrase "sociological excuses"). Lahire seeked to detach sociological explanations of social problems and behaviors from any normative purpose. Reasserting sociology's independence from moral and political

\footnotetext{
${ }^{2}$ Jean-Claude Passeron has discussed this concept of objectabilité during a radio interview he gave to France Culture in 2001: https://www.franceculture.fr/sociologie/qui-veut-la-peau-de-la-sociologie.
} 
considerations, the French sociologist underlined that the original goal of the discipline is more to understand and decipher social phenomena than to attribute responsibilities or to sustain accusations of any sort (Lahire 2016, p. 44; see also p. 157). In this regard, the sociologist is no different from the physicist trying to shed light on subatomic particles.

Far from being merely symbolic, sociology's lack of authority directly impacts its funding and perspectives of development. As I am writing this editorial, there is an ongoing controversy among French sociologists and social scientists after the Institut des sciences humaines et sociales of the CNRS (French National Center for Scientific Research) has made the results of the entry exam public. The process of entry to the CNRS is divided into two steps. The first step involves the section's committee, ${ }^{3}$ in this case the section 36 sociology and law. CNRS sections receive the applications and rank the candidates according to their academic credentials, list of publications and proposed research project. Among the candidates to the section 36 sociology and law, six researchers were pre-selected by the committee: four sociologists, and two legal scholars. While not legally binding, this ranking is generally followed by the central committee of the Institut des sciences humaines et sociales. Indeed, since sections' committees are specialized, they are in a better position to know what's best for their field. But the 2017 jury ignored the section 36's proposed ranking and decided to appoint the two legal scholars only (out of the six candidates ranked by the section 36), even though three researcher positions were available. ${ }^{4}$ The Institut preferred to attribute the third researcher position to another disciplinary section rather than hiring one of the four ranked sociologists. This decision has been perceived by French sociologists, and social scientists more generally, as a direct attack against sociology's independence and authority as a scientific discipline. A petition that has been uploaded online to contest this decision has already been signed by hundreds of researchers, including some of the most visible French sociologists and social scientists (including Thomas Piketty, Frédéric Lebaron, current president of the Association française de sociologie, or Bernard Lahire). ${ }^{5}$

I believe that this political response might fruitfully be followed by a scientific one. Although it is never a pleasant task to delve into our own discipline's weaknesses, it might serve sociology and social sciences more generally to get a better understanding of the construction of social scientists' social authority. To be sure, some quality works have addressed the historical development of French sociology, including sociologists' successful attempt to pull away from the humanities and law (Heilbron 2015; Karady 1979; Mucchielli 2010). Yet, we know much less about the most recent developments. I am not the first to remark that sociologists' and historians' interest in the development and crystallization of disciplines has mostly focused on natural "hard" sciences (Morgan and Baert 2015, p. 8). Apart from episodic publications such as Yves Gingras' collective book featuring thorough analyses of scientific controversies in social sciences and humanities, (2014), the efforts of sociologists and historians of science have converged around ideal-typical scientific fields operating through a unique dominant

\footnotetext{
${ }^{3}$ The CNRS is organized in disciplinary sections.

${ }^{4}$ Sections 35 (comprising history and philosophy of science) and 39 (urban and rural studies, territories and societies) are also concerned.

${ }^{5} \mathrm{https}$ ://www.change.org/p/président-du-cnrs-concours-cnrs-2017-la-sociologie-déclassée-l-autonomiescientifique-remise-en-cause.
} 
Kuhnian paradigm, such as physics or molecular biology. This, I suspect, has had the insidious consequence of reproducing and reinforcing the social hierarchy between social and natural sciences. Maybe it is time to revise our interests.

Acknowledgements I would like to express my deepest gratitude to the journal editor, Lawrence Nichols, for his enthusiasm and interest in the state of sociology in France. It has been a pleasure to work with him on this exciting project. Lawrence Nichols and I have tried to primarily focus on the current state of French sociology, rather than on its history and past forms. For those readers who are more interested in historical analyses, we can only refer to the plethora of thorough investigations that addressed the works of Durkheim and his legacy (see for instance Heilbron 2015). Some of the featured papers do include historical perspectives (in particular Meszaros 2017; Mucchielli 2017).

\section{References}

Brahim, R. (2017). What About a Sociology of Ethnicity in France? A Foucaldian Reading of Racial Violence. The American Sociologist, forthcoming.

Burnay, N., Hummel, C., \& Voléry, I. (2017). The Kaleidoscope of the Sociology of Aging Seen through the French-Speaking Field. The American Sociologist, 1-24.

Faber, A. (2017). From False Premises to False Conclusions. On Pierre Bourdieu's Alleged Sociological Determinism. The American Sociologist, 1-17.

Gingras, Y. (Ed.). (2014). Controverses : Accords et désaccords en sciences humaines et sociales. Paris: Editions CNRS.

Heilbron, J. (2015). French Sociology. Ithaca: Cornell University Press.

Jeannin, H. (2017). Being a Corporate Sociologist... an Insider's View. The American Sociologist, 1-19.

Karady, V. (1979). Stratégies de réussite et modes de faire-valoir de la sociologie chez les durkheimiens. Revue Française de Sociologie, 20(1), 49-82.

Lahire, B. (2016). Pour la sociologie. Paris: La Découverte.

Larregue, J. (2017). Who is Emmanuel Todd? The American Sociologist, 1-2.

Lefaucheur, N., \& Kabile, J. (2017). Sociology of gender in the French Caribbean: a slow and fragile process. The American Sociologist, forthcoming.

Masson, P., \& Schrecker, C. (2017). How does the individual find a place in French sociology?. The American Sociologist, forthcoming.

Meszaros, T. (2017). The French Tradition of Sociology of International Relations: An Overview. The American Sociologist, 1-45.

Morgan, M., \& Baert, P. (2015). Conflict in the Academy: A Study in the Sociology of Intellectuals. Basingstoke: Palgrave Macmillan.

Mucchielli, L. (2010). La découverte du social : Naissance de la sociologie en France. Paris: La Découverte.

Mucchielli, L. (2017). Sociology of Deviance and Criminology in France: History and Controversies. The American Sociologist, 1-21.

Ollion, E., \& Abbott, A. (2016). French Connections: The Reception of French Sociologists in the USA (1970-2012). European Journal of Sociology / Archives Européennes de Sociologie, 57(2), 331-372.

Passeron, J.-C. (2013). Le Raisonnement sociologique : un espace non poppérien de l'argumentation. Paris: Albin Michel.

Penalva-Icher, E., \& Eloire, F. (2017). Networking in France. Is there a French school of Social Network Analysis?. The American Sociologist, forthcoming.

Raoult, S., Leonard, B., \& Derbey, A. (2017). A Prophet in his Hometown? The Academic Reception of Thomas Piketty's "Capital in the Twenty-First Century" Across Disciplines in France and in the United States. The American Sociologist, 1-23.

Sepulvado, B., \& Lizardo, O. (2017). Cognitive Sociology in France. The American Sociologist, 1-16.

Verjus, A. (2017). A Disputed Truth. Defending Emmanuel Todd's Approach of Je suis Charlie. The American Sociologist, 1-26. 